\title{
Modification of energy metabolism by the presence of the gut microflora in the chicken
}

\author{
BY T. MURAMATSU*, S. NAKAJIMA AND J. OKUMURA \\ Laboratory of Animal Nutrition, School of Agricultural Sciences, Nagoya University, Chikusa-ku, \\ Nagoya 464-01, Japan
}

(Received 16 June 1993 - Revised 13 August 1993-Accepted 24 August 1993)

\begin{abstract}
Whether the association with gut microflora modifies the energy metabolism of chickens was investigated by varying the metabolizable energy consumption level from zero to above the maintenance requirement in the germ-free and conventional states. Single comb White Leghorn chicks were either fasted for $3 \mathrm{~d}$ (Expt 1), or fed for $6 \mathrm{~d}$ at a fixed daily meal intake of 2,5 or $8 \mathrm{~g} / \mathrm{d}$ (Expt 2), or 5,10 or $15 \mathrm{~g} / \mathrm{d}$ (Expt 3). Changes in carcass energy deposition and heat production indicated that when no dietary energy was available the presence of the gut microflora could benefit the birds by reducing energy losses, whereas when dietary energy was supplied the efficiency of energy utilization was reduced by the presence of the gut microflora. It was concluded, therefore, that the heavy burden of the gut microflora modifies energy metabolism by exerting a buffering or a counter-productive action on the energy utilization of the chicken.
\end{abstract}

Gut microflora: Energy utilization: Chickens: Carcass energy deposition: Heat production

The presence of normal gut microflora may affect the metabolism of host birds in various ways. In protein metabolism, for example, little or no effect on overall protein utilization was produced by the presence of the gut microflora (Salter \& Coates, 1971). When birds were subjected to protein starvation, however, the excretion of endogenous $\mathrm{N}$ was lowered in the conventional (CV) state compared with the germ-free (GF) state (Salter et al. 1974; Okumura et al. 1978). A more pronounced difference was found in protein synthesis of tissues that are in direct contact or close association with the gut micro-organisms. Protein synthesis in the gut mucosa and the lower gut was increased by the presence of the gut microflora (Muramatsu et al. 1983, 1987, 1988 b, 1993), whereas little effect was found in skeletal muscle (Muramatsu et al. 1985).

In the past, the impact of the gut microflora on the energy metabolism of host birds has not been extensively studied. Hegde $e t$ al. (1982) have reported that dietary metabolizable energy (ME) values are marginally but significantly increased by the presence of the gut microflora, suggesting that chickens can utilize extra amounts of dietary energy extracted through the action of gut bacteria. Indeed, it has been shown that when chickens are fed on a low-energy, high-fibre diet, the energy extracted from dietary-fibre digestion by bacterial action can be efficiently utilized for growth of the host bird (Muramatsu et al. 1991).

The gut microflora can modify energy conversion and utilization in the chicken not only at a digestion step but also at an internal metabolism step. Furuse \& Yokota (1984) have suggested, from the results of multiple regression, that the association with the gut bacteria increases the maintenance energy requirement of the chicken. On the other hand, fasting heat production is decreased by the association with the gut microflora (Muramatsu et al. 
$1988 a$ ). It appears, therefore, that the presence of the gut microflora may play either a buffering or a counter-productive action in energy utilization of birds, i.e. saving the heat loss when no energy supply is available, but lowering the energy utilization when normal growth is maintained.

The above hypothesis of the counter-productive effect, however, has not been substantiated because no attempt has ever been made in the CV and GF states to quantify energy utilization and $\mathrm{ME}$ intake level with a wide range from zero to an amount above the maintenance requirement in chickens. The present study was conducted, therefore, to investigate the relationship between energy utilization of the chicken and the association with the gut microflora by varying the level of $\mathrm{ME}$ intake.

\section{MATERIALS AND METHODS}

Animals and diets

The birds were cared for under Guidelines for Animal Experimentation, laid down by the Committee of Experimental Animal Care, Nagoya University, Japan.

Fertilized eggs from single-comb White Leghorn hens and cocks, which were supplied from Gifu Poultry Experimental Station, Gifu, Japan, and kept in our poultry house, were incubated in a clean incubator. The details of the method for producing GF birds have been described elsewhere (Yokota et al. 1984). The hatched chicks were reared in pairs in metabolism cages, and were given free access to a commercial diet (Chick 15; Marubeni Shiryou Co. Ltd, Tokyo, Japan), which was fortified with vitamins to compensate for the possible loss due to ${ }^{60} \mathrm{Co}$ irradiation sterilization (Coates et al. 1963), until $9 \mathrm{~d}$ of age in either GF or CV states. At this stage, twenty-two, sixty, and eighteen birds with similar body weights from both GF and CV groups were selected in Expts 1, 2, and 3, respectively. In Expts 2 and 3 the birds were then distributed into three experimental groups of twenty and six birds respectively, in each gut environment. The average body weights of GF and CV birds were (mean (SEM)) : Expt 1, 71.4 (1.6) and 67.7 (1.8) g; Expt 2, 75.1 (0.6) and 75.3 $(1 \cdot 5) \mathrm{g}$; and Expt $3,74 \cdot 6(2 \cdot 1)$ and $72 \cdot 3(1 \cdot 6) \mathrm{g}$ respectively.

In Expt 1 the birds were fed on a semi-purified experimental diet for the following $3 \mathrm{~d}$ and subsequently fasted for $3 \mathrm{~d}$, while in Expts 2 and 3 the birds were given the same semipurified experimental diet at a fixed amount of 2, 5 or $8 \mathrm{~g} / \mathrm{d}$ (Expt 2), and 5, 10 or $15 \mathrm{~g} / \mathrm{d}$ (Expt 3), for the following $6 \mathrm{~d}$. The composition of the semi-purified experimental diet is given in Table 1. In all experiments, the chicks were allowed free access to water. The ambient temperature was maintained at $28 \pm 2^{\circ}$ throughout the experimental period, and light was provided continuously for $24 \mathrm{~h} / \mathrm{d}$. During the experimental period, body weight and food consumption were recorded at $3 \mathrm{~d}$ intervals.

At the beginning of the fasting period ( $12 \mathrm{~d}$ of age) in Expt 1 , and at the middle of the feeding period ( $12 \mathrm{~d}$ of age) in Expts 2 and 3, half the birds assigned to each dietary treatment in both $\mathrm{CV}$ and GF states were killed by neck dislocation to determine initial carcass composition. Subsequently, at the end of the experimental period ( $15 \mathrm{~d}$ of age) the remaining birds were killed similarly by neck dislocation, and the carcass samples were stored at $-20^{\circ}$ until analysis. In all experiments the droppings were collected in $300 \mathrm{ml}$ $0.05 \mathrm{M}-\mathrm{HCl}$ for the last $3 \mathrm{~d}$ from 12 to $15 \mathrm{~d}$ of age to determine the $\mathrm{ME}$ value of the experimental diet.

\section{Chemical analysis}

The preparation of the carcass and excreta samples has been described elsewhere in detail (Muramatsu \& Okumura, 1985). The $\mathrm{N}$ contents of the diet, excreta and carcass were determined by a Kjeldahl method, and carcass protein was calculated as $\mathrm{N} \times 6.25$. Carcass 
Table 1. Composition of the experimental diet $(\mathrm{g} / \mathrm{kg})$

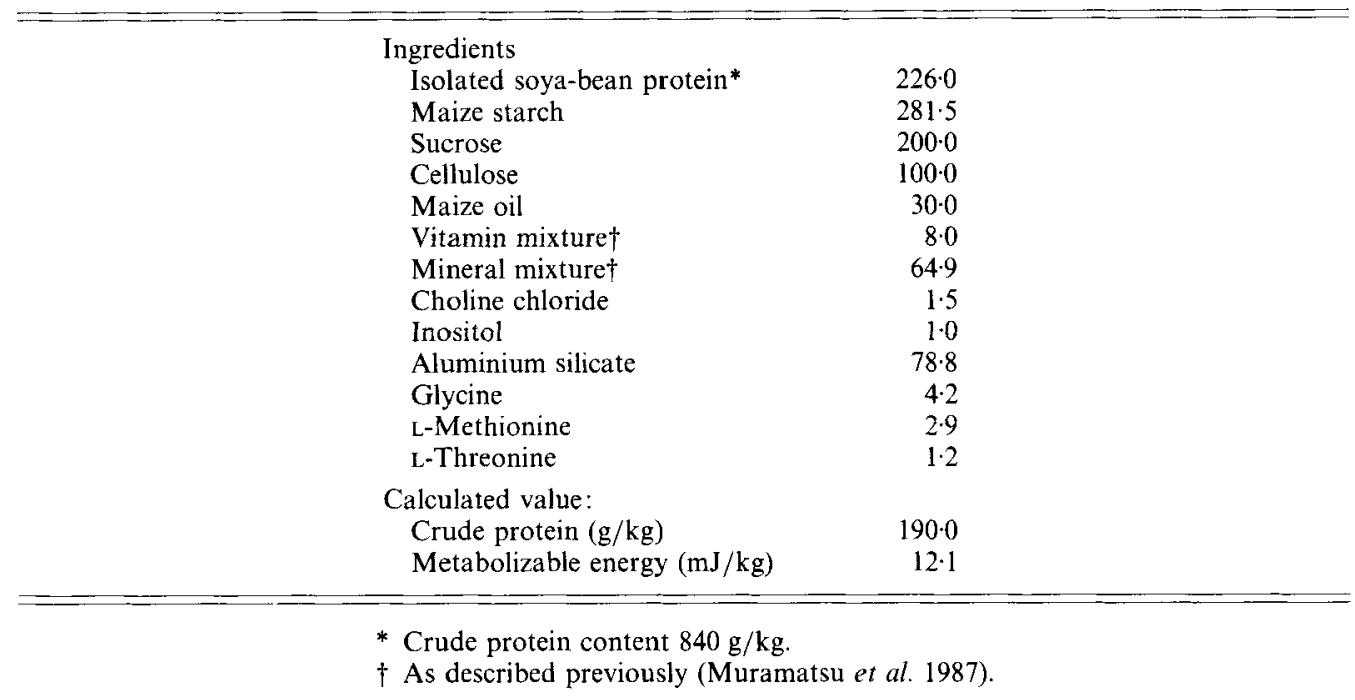

fat was determined gravimetrically after extraction with diethyl ether. Retained energy in the carcass and heat production were calculated as described previously (Muramatsu et al. $1988 a$ ). The values for changes in carcass fat, protein and energy, and those for heat production were expressed on a unit body weight basis to eliminate a possible effect of differences in body weight between the two gut environments. Dietary ME value was calculated after correction for retained $\mathrm{N}$ as described by Hill \& Anderson (1958).

\section{Statistical analysis and calculation}

Statistical treatment was done by a one-way analysis of variance (Expt 1) and a $2 \times 3$ factorial analysis of variance (Expts 2 and 3) with the General Linear Model procedures of SAS (Statistical Analysis Systems Institute Inc., 1985) to assess the significance of the main effects of gut environment, and feeding level, and the interaction. For comparison of means of main effects, and of individual treatments, a protected last significant difference method was used (Snedecor \& Cochran, 1980). The significance of differences between individual treatment means within the same gut environment or within the same feeding level was not tested unless a significant interaction was detected. For the pooled data from Expts 1, 2 and 3, linear regression of carcass energy deposition or heat production on ME intake was done, and the slopes and intercepts between the CV and GF states were compared (Snedecor \& Cochran, 1980).

\section{RESULTS}

The values for body weight, carcass fat and protein contents, and the deposition of carcass fat and protein over the $3 \mathrm{~d}$ fasting period are given in Table 2 . The initial body weight before fasting was significantly higher in the GF birds than in the CV controls, while after $3 \mathrm{~d}$ fasting no significant difference was detected. After fasting for $3 \mathrm{~d}$ the carcass fat concentration was significantly higher in the GF chicks than in the CV counterparts, whereas no difference was found in the carcass protein concentration. Carcass fat deposition over the $3 \mathrm{~d}$ fasting period showed a significantly larger loss in the GF state than in the CV state with no difference in carcass protein deposition. 
Table 2. Expt 1. Body weight $(B W)$, carcass fat and protein concentrations, and fat and protein depositions after fasting for $3 d$ in germ-free $(G F)$ and conventional $(C V)$ chickst

\begin{tabular}{lcccc}
\hline Gut environment ... & CV & GF & Pooled se & $\begin{array}{c}\text { Statistical } \\
\text { significance } \\
\text { of effect }\end{array}$ \\
$n \ldots$ & 11 & 11 & $(20 \mathrm{~d})$ & \\
\hline BW before fasting (g) & $83 \cdot 6$ & $90 \cdot 1$ & $2 \cdot 5$ & $*$ \\
BW after fasting (g) & $63 \cdot 9$ & $71 \cdot 6$ & $3 \cdot 8$ & $\mathrm{NS}$ \\
Carcass fat $(\mathrm{g} / \mathrm{kg})$ & 30 & 46 & 3 & $* *$ \\
Carcass protein $(\mathrm{g} / \mathrm{kg})$ & 187 & 185 & 2 & $\mathrm{NS}$ \\
Fat deposition $(\mathrm{g} / \mathrm{kg} \mathrm{BW}$ per d) & -14 & -18 & 1 & $* *$ \\
Protein deposition $(\mathrm{g} / \mathrm{kg} \mathrm{BW}$ per d) & -10 & -11 & 1 & $\mathrm{NS}$ \\
\hline
\end{tabular}

Significance level: NS, not significant; ${ }^{*}, P<0 \cdot 05 ;{ }^{* *}, P<0 \cdot 01$.

+ For details of birds and procedures, see pp. $710-711$.

Table 3. Expt 2. Effect of restricted feeding on body weight $(\mathrm{g})$, carcass fat and protein concentrations $(\mathrm{g} / \mathrm{kg})$, fat and protein depositions $(\mathrm{g} / \mathrm{kg}$ body $w \mathrm{t} \mathrm{per} \mathrm{d)}$, and dietary metabolizable energy $(M E)$ value $(k J / g)$ in germ-free $(G F)$ and conventional $(C V)$ chicks $\ddagger$

\begin{tabular}{|c|c|c|c|c|c|c|c|c|}
\hline \multirow{2}{*}{$\begin{array}{l}\text { Gut } \\
\text { environment } \\
\text { (E) }\end{array}$} & \multirow{2}{*}{$\begin{array}{c}\text { Food } \\
\text { intake level } \\
(\mathrm{FI}) \\
(\mathrm{g} / \mathrm{d})\end{array}$} & \multirow[b]{2}{*}{$n$} & \multirow{2}{*}{$\begin{array}{l}\text { Body } \\
\text { wt }\end{array}$} & \multicolumn{2}{|c|}{ Carcass } & \multicolumn{2}{|c|}{ Deposition of } & \multirow{2}{*}{$\begin{array}{c}\mathrm{ME} \\
\text { value }\end{array}$} \\
\hline & & & & Fat & Protein & Fat & Protein & \\
\hline Group mean & $\begin{array}{l}2 \\
5 \\
8\end{array}$ & $\begin{array}{r}10 \\
10 \\
9\end{array}$ & $\begin{array}{l}62 \cdot 1 \\
77 \cdot 2 \\
92 \cdot 9 \\
77 \cdot 4\end{array}$ & $\begin{array}{l}37 \cdot 6 \\
44 \cdot 9 \\
52 \cdot 2 \\
45 \cdot 0\end{array}$ & $\begin{array}{l}182 \\
180 \\
178 \\
180\end{array}$ & $\begin{array}{l}-7 \cdot 1 \\
-6.9 \\
-5 \cdot 0 \\
-6.3\end{array}$ & $\begin{array}{r}-5 \cdot 3 \\
1.2 \\
4.9 \\
0 \cdot 2\end{array}$ & $\begin{array}{r}8 \cdot 7 \\
11 \cdot 6 \\
12 \cdot 1 \\
10 \cdot 8\end{array}$ \\
\hline Group mean & $\begin{array}{l}2 \\
5 \\
8\end{array}$ & $\begin{array}{r}10 \\
9 \\
8\end{array}$ & $\begin{array}{l}65 \cdot 1 \\
80 \cdot 6 \\
95 \cdot 7 \\
80 \cdot 5\end{array}$ & $\begin{array}{l}42 \cdot 1 \\
55 \cdot 3 \\
50 \cdot 8 \\
49 \cdot 4\end{array}$ & $\begin{array}{l}189 \\
188 \\
185 \\
187^{* *}\end{array}$ & $\begin{array}{l}-7 \cdot 6 \\
-8 \cdot 5 \\
-4 \cdot 0 \\
-6.7\end{array}$ & $\begin{array}{r}-7 \cdot 0 \\
-1 \cdot 2 \\
4 \cdot 6 \\
-1 \cdot 2^{*}\end{array}$ & $\begin{array}{l}8 \cdot 3 \\
11 \cdot 0 \\
11 \cdot 6 \\
10 \cdot 3^{* *}\end{array}$ \\
\hline $\begin{array}{l}\mathrm{SE}(50 \mathrm{df}) \text { for: } \\
\text { Group means } \\
\text { Individual means }\end{array}$ & $\mathrm{df}$ & & $\begin{array}{l}1 \cdot 1 \\
2 \cdot 0\end{array}$ & $\begin{array}{l}1 \cdot 7 \\
3 \cdot 0\end{array}$ & $\begin{array}{l}\quad \begin{array}{l}1 \cdot 1 \\
2 \cdot 0\end{array} \\
\text { nalysis of v } \\
\text { Mean squ }\end{array}$ & $\begin{array}{r}0.5 \\
0.9 \\
\text { lance } \\
\text { e }\end{array}$ & $\begin{array}{l}0.4 \\
0.7\end{array}$ & $\begin{array}{l}0.12 \\
0.21\end{array}$ \\
\hline $\begin{array}{l}\mathrm{E} \\
\mathrm{FI} \\
\mathrm{E} \times \mathrm{FI} \\
\text { Residual }\end{array}$ & $\begin{array}{r}1 \\
2 \\
2 \\
50\end{array}$ & & $\begin{array}{c}131 \\
8633+\uparrow \\
1 \\
36\end{array}$ & $\begin{array}{l}2 \cdot 71 \\
7 \cdot 68+\dagger \\
1 \cdot 51 \\
0.82\end{array}$ & $\begin{array}{l}7.02 \dagger \dagger \\
0.81 \\
0.02 \\
0.36\end{array}$ & $\begin{array}{l}0.02 \\
0.52 \dagger \\
0.07 \\
0.08\end{array}$ & $\begin{array}{l}0.28 \dagger \\
4.87 \dagger \dagger \\
0.05 \\
0.05\end{array}$ & $\begin{array}{c}2.89 \dagger \dagger \\
54.57+\dagger \\
0.07 \\
0.40\end{array}$ \\
\hline
\end{tabular}

Mean value was significantly different from that for $\mathrm{CV}$ chicks: ${ }^{*} P<0.05,{ }^{* *} P<0 \cdot 01$.

$\dagger, P<0.05 ; \dagger \dagger, P<0.01$.

$\$$ For details of diets and procedures, see Table 1 and pp. $710-711$.

Table 3 gives the values for final body weight, carcass fat and protein concentrations, carcass fat and protein depositions, and dietary ME in Expt 2. There was a tendency for higher body weight in the GF chickens than in the CV controls, but this was not significant. The final carcass protein concentration was significantly lower in the $\mathrm{CV}$ than in the GF chicks, but the carcass fat concentration was not significantly different between the two gut 
Table 4. Expt 3. Effect of moderately restricted feeding on body weight $(\mathrm{g})$, carcass fat and protein concentrations $(\mathrm{g} / \mathrm{kg})$, fat and protein depositions $(\mathrm{g} / \mathrm{kg}$ body wt per $\mathrm{d})$, and dietary metabolizable energy $(M E)$ value $(\mathrm{kJ} / \mathrm{g})$ in germ-free $(G F)$ and conventional $(C V)$ chicks $\ddagger$

\begin{tabular}{|c|c|c|c|c|c|c|c|c|}
\hline \multirow{2}{*}{$\begin{array}{l}\text { Gut } \\
\text { environment } \\
\text { (E) }\end{array}$} & \multirow{2}{*}{$\begin{array}{c}\text { Food } \\
\text { intake level } \\
(\mathrm{FI}) \\
(\mathrm{g} / \mathrm{d})\end{array}$} & \multirow[b]{2}{*}{$n$} & \multirow{2}{*}{$\begin{array}{c}\text { Body } \\
\text { wt }\end{array}$} & \multicolumn{2}{|c|}{ Carcass } & \multicolumn{2}{|c|}{ Deposition of } & \multirow{2}{*}{$\begin{array}{c}\text { ME } \\
\text { value }\end{array}$} \\
\hline & & & & Fat & Protein & Fat & Protein & \\
\hline Group mean & $\begin{array}{r}5 \\
10 \\
15\end{array}$ & $\begin{array}{l}3 \\
3 \\
3\end{array}$ & $\begin{array}{r}75 \cdot 3 \\
105 \cdot 0 \\
119 \cdot 0 \\
99 \cdot 8\end{array}$ & $\begin{array}{l}30 \cdot 3 \\
49 \cdot 5 \\
55 \cdot 0 \\
45 \cdot 0\end{array}$ & $\begin{array}{l}182 \\
178 \\
170 \\
177\end{array}$ & $\begin{array}{r}-5 \cdot 4 \\
2 \cdot 8 \\
1 \cdot 1 \\
-0.5\end{array}$ & $\begin{array}{l}1 \cdot 1 \\
4 \cdot 9 \\
6 \cdot 2 \\
4 \cdot 1\end{array}$ & $\begin{array}{l}12 \cdot 2 \\
12 \cdot 3 \\
12 \cdot 5 \\
12 \cdot 4\end{array}$ \\
\hline Group mean & $\begin{array}{r}5 \\
10 \\
15\end{array}$ & $\begin{array}{l}3 \\
3 \\
3\end{array}$ & $\begin{array}{c}85 \cdot 0 \\
106 \cdot 3 \\
124 \cdot 0 \\
105 \cdot 1\end{array}$ & $\begin{array}{l}34 \cdot 4 \\
48 \cdot 1 \\
70 \cdot 0 \\
50 \cdot 9\end{array}$ & $\begin{array}{l}186 \\
183 \\
175 \\
181\end{array}$ & $\begin{array}{r}-8.8 \\
-1.5 \\
1.0 \\
-3.1\end{array}$ & $\begin{array}{l}2 \cdot 0 \\
6 \cdot 3 \\
9 \cdot 8 \\
6 \cdot 0\end{array}$ & $\begin{array}{l}11 \cdot 3 \\
11 \cdot 7 \\
11 \cdot 7 \\
11 \cdot 5^{* *}\end{array}$ \\
\hline $\begin{array}{l}\text { SE }(12 \mathrm{df}) \text { for: } \\
\text { Group means } \\
\text { Individual means }\end{array}$ & & & $\begin{array}{l}1.8 \\
3.1\end{array}$ & $\begin{array}{l}3 \cdot 0 \\
5 \cdot 3\end{array}$ & $\begin{array}{l}2 \cdot 2 \\
3 \cdot 7\end{array}$ & $\begin{array}{l}1.0 \\
1.7\end{array}$ & $\begin{array}{l}0.6 \\
1.1\end{array}$ & $\begin{array}{l}0 \cdot 11 \\
0.20\end{array}$ \\
\hline Source & $\mathrm{df}$ & & & & $\begin{array}{c}\text { nalysis } \\
\text { Mean }\end{array}$ & nce & & \\
\hline $\begin{array}{l}\mathrm{E} \\
\mathrm{FI} \\
\mathrm{E} \times \mathrm{FI} \\
\text { Residual }\end{array}$ & $\begin{array}{r}1 \\
2 \\
2 \\
50\end{array}$ & & $\begin{array}{c}128 \\
5129+\dagger \\
52 \\
28\end{array}$ & $\begin{array}{c}1.57 \\
13.66 \dagger \dagger \\
1.04 \\
0.83\end{array}$ & $\begin{array}{l}0.99 \\
3.89 \dagger \\
0.02 \\
0.42\end{array}$ & $\begin{array}{l}0.30 \\
2.53 \dagger \dagger \\
0.16 \\
0.09\end{array}$ & $\begin{array}{l}0.17 \\
1.25 \dagger \dagger \\
0.03 \\
0.04\end{array}$ & $\begin{array}{l}3.02+7 \\
0.47 \\
0.05 \\
0.12\end{array}$ \\
\hline
\end{tabular}

Mean value was significantly different for $\mathrm{CV}$ chicks: ${ }^{* *} P<0 \cdot 01$.

$\dagger, P<0.05 ; \dagger \dagger, P<0.01$.

$\ddagger$ For details of diets and procedures, see Table 1 and pp. 710-711.

environments. Carcass protein deposition was significantly lower in the GF birds than in the CV controls, whereas no difference was detected in carcass fat deposition. Dietary ME values were significantly higher in the CV than in the GF state.

The values for final body weight, carcass fat and protein concentrations, carcass fat and protein depositions, and dietary ME in Expt 3 are given in Table 4. The final body weight tended to be higher in the GF birds than in the CV controls, but this was not significant. Concentrations and deposition of carcass fat and protein were not significantly different between the two gut environments. Dietary ME values were significantly higher in the $\mathrm{CV}$ state than those in the GF state.

Using the pooled data from all the experiments, regression lines of energy deposition or heat production on ME intake were compared between the $\mathrm{CV}$ and GF states. The regression lines with calculated equations in the $\mathrm{CV}$ and GF states are presented in Fig. 1 together with the analysis of variance for the comparison in Table 5. The comparison showed that in both energy deposition and heat production the elevation term was significant, indicating a significant difference in the intercepts between the CV and GF states. In addition the parallelism term was significant, indicating a significant difference in the slopes between the two gut environments. For energy deposition the intercept was lower in the GF than in the CV states, whereas the reverse was true for the slopes. The regression lines for heat production showed the opposite trend to carcass energy deposition; the 

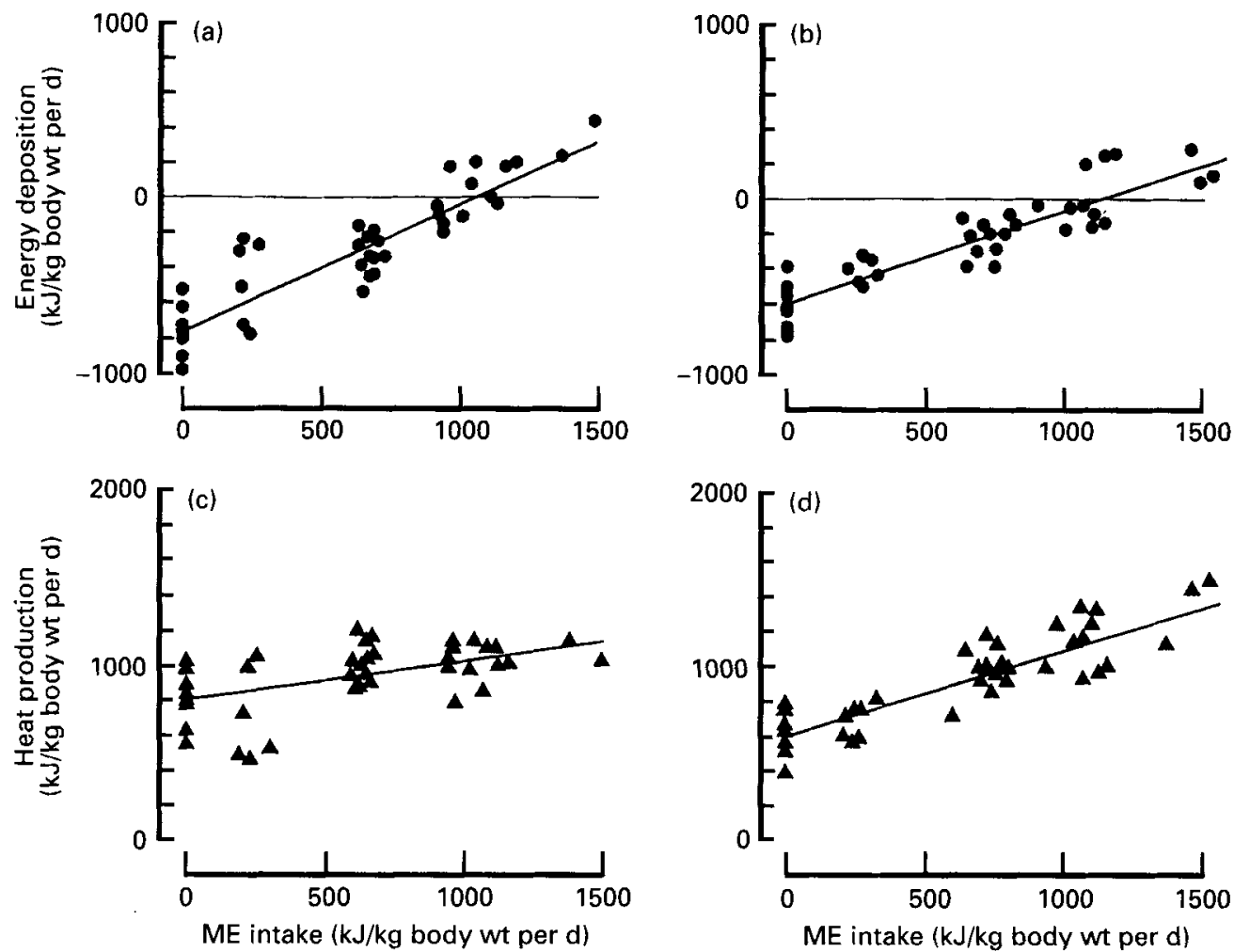

Fig. 1. The relationship between energy deposition (a, b) or heat production (c, d) and metabolizable energy (ME) intake levels varying from zero to above the maintenance requirement in the chicken reared in a germ-free $(a, c)$ or conventional $(b, d)$ state. For regression equations, see footnote to Table 5.

Table 5. Analysis of variance for regression of heat production and carcass energy deposition on metabolizable energy $(M E)$ intake when chicks were reared in germ-free $(G F)$ and conventional $(C V)$ environments, and subjected to fasting or restricted feeding $\dagger$

\begin{tabular}{lccc}
\hline \hline $\begin{array}{l}\text { Output variable... } \\
\text { Source }\end{array}$ & df & $\begin{array}{c}\text { Energy deposition } \\
\text { Mean square }\end{array}$ & $\begin{array}{c}\text { Heat production } \\
\text { Mean square }\end{array}$ \\
ME intake & 1 & $77351^{* * *}$ & $25441^{* * *}$ \\
Elevation between gut environments & 1 & $2133^{* * *}$ & $1941^{* * *}$ \\
Parallelism between gut environments & 1 & $1986^{* * *}$ & $2016^{* * *}$ \\
Residual & 84 & $157^{2}$ & 156 \\
\hline
\end{tabular}

$* * *, P<0.001$.

$\dagger$ Results from experiments 1,2 , and 3 were pooled. For details, see pp. 710-711.

The regression equations obtained for carcass energy deposition or heat production $(\mathrm{kJ} / \mathrm{kg}$ body weight per $\mathrm{d})$ on $\mathrm{ME}$ intake $(\mathrm{kJ} / \mathrm{kg}$ body weight per $\mathrm{d})$ were :

Energy deposition (GF) $\quad=-766.9+0.729 \times \mathrm{ME}$ intake $\quad(r 0.92, P<0.001)$

Energy deposition $(\mathrm{CV}) \quad=-605.8 \ddagger+0.523 \ddagger \times \mathrm{ME}$ intake $(r 0.92, P<0.001)$

SE for coefficient $\begin{array}{ll}43 \cdot 7 & 0 \cdot 058\end{array}$

comparison

Heat production (GF) $\quad=766.0+0.265 \times$ ME intake $\quad(r 0.66, P<0.001)$

Heat production $(\mathrm{CV}) \quad=612.3 \ddagger+0.473 \ddagger \times \mathrm{ME}$ intake $\quad(r 0.90, P<0.001)$ SE for coefficient $43.5 \quad 0.058$

comparison

$\ddagger$ Significantly different from the corresponding GF value; $P<0.001$ 
intercept was lower in the CV than in the GF state, and the slope was higher in the CV birds than in their GF counterparts.

\section{DISCUSSION}

The results of the present study indicate that carcass energy deposition and heat production in relation to varying $\mathrm{ME}$ consumption levels, from zero to above the maintenance requirement, are affected by the association with the normal gut microflora in the chicken. In the fasting state, heat production, calculated as energy loss from the carcass, was lower in the CV birds than in their GF counterparts as indicated by changes in the intercepts of the regression lines on ME intake levels. This confirmed our previous findings of lower fasting heat production (Muramatsu et al. 1988a), and was in line with the lower body temperature in the CV chickens (Harrison \& Hewitt, 1978; Muramatsu et al. 1988a). It follows, therefore, that the presence of the gut microflora may benefit the host birds by saving energy loss from the body when no dietary energy supply is available. On the other hand, the efficiency of dietary energy utilization as indicated by changes in slopes of the regression lines on ME intake levels was lowered by the burden of the gut micro-organisms. This is also in line with the implication from previous findings (Furuse \& Yokota, 1984). Thus, the present results clearly substantiate the hypothesis of the buffering or counterproductive action of the gut microflora on energy metabolism in the chicken.

If the counter-productive action of the gut microflora on the energy metabolism of host birds does really exist, then a question may arise as to how it can be attained. At present, the exact mechanism is not known, but the action might be explained at different steps. First, dietary ME values were significantly increased by the presence of the gut bacteria (Tables 3 and 4). The difference in the dietary ME values between the two gut environments would be largely accounted for by the difference in the digestibility of energy sources, predominantly dietary fibre (Muramatsu et al. 1991). Accordingly, the modifications of the host energy utilization by the gut microflora might occur at the digestion step where the most likely products of carbohydrate (including dietary fibre) degradation would be monosaccharides with a relatively small amount of volatile fatty acids, which would serve as a poor source of metabolic fuel (Bolton \& Dewar, 1965; Yoshida et al. 1970; Baker, 1977; Furuse \& Okumura, 1989). The production of volatile fatty acids in the gut may account, at least in part, for the higher ME value but lower efficiency for net energy deposition in the chicken harbouring the gut microflora. Second, the association with the gut microflora might cause increases in energy cost by modifying the rate of energyconsuming reactions such as protein turnover within the chicken body. This is certainly true for the gastrointestinal tract in the chicken when the gut micro-organisms are present (Muramatsu et al. 1983, 1987, 1988 b, 1993). The energy cost of protein synthesis would account for approximately 20 to $30 \%$ of the total heat production in the chicken (Muramatsu \& Okumura, 1985). By assuming that the energy cost of protein synthesis in vivo is $5.4 \mathrm{~kJ} / \mathrm{g}$ (Aoyagi et al. 1989), at least a few percent of increased heat production, i.e. energy waste, in the $\mathrm{CV}$ state is expected. As protein degradation also requires energy at about a quarter of that needed for protein synthesis (Harris \& Lobley, 1991), the extra waste of energy derived from body protein degradation in the CV state should be added to the above energy waste due to protein synthesis.

In mammalian species, modification of energy metabolism by the presence of the gut microflora has been suggested from studies with antibiotics. Supplementing a diet with an antibiotic, and thereby suppressing the microbial activity in the diet, increased dietary energy utilization in rats (Eggum \& Chwalibog, 1983). Yen et al. (1985) also demonstrated that fasting heat production was reduced by feeding an antibiotic to the pig. Although the results with the pig (Yen et al. 1985) are in contrast to our findings in the chicken, the 
contradiction might be attributable to species differences. Alternatively, it may mean that the antibiotic used in the pig study could have affected the fasting heat production not only by suppressing the activity of the gut microflora in the digestive tract but also by directly inhibiting the metabolic rate per se.

In the present study, further partition of energy utilization, i.e. partial efficiency of protein and fat energy depositions, was not compared between the two gut environments. When the heat production or ME intake were regressed on protein and fat energy depositions, partial efficiency coefficients could be obtained for the CV and GF chickens. In theory, this method should be able to clarify the issue of which form of energy deposition (protein or fat) is more susceptible to the association with the gut microflora. However, it was shown that there was a high correlation between protein and fat energy depositions $(r$ $=0.698, P<0.0001)$ in the present study. This was attributable to the experimental design used which caused changes in protein and fat depositions in the same direction by varying feed intake, and hence ME intake level. The existence of this high multicollinearity interfered with the accurate estimation of partial efficiency of energy utilization for each component. Consequently, if a more detailed analysis were to be carried out using a multiple regression, protein and fat energy depositions should be manipulated separately and independently. This could be achieved by systematically varying levels of dietary protein and ME intakes at the same time.

\section{REFERENCES}

Aoyagi, Y., Tasaki, I., Okumura, J. \& Muramatsu, T. (1989). Energy cost of whole-body protein synthesis measured in vivo in chicks. Comparative Biochemistry and Physiology 91A, 765-768.

Baker, D. H. (1977). Xylose and xylan utilization by the chick. Poultry Science 56, 2105-2107.

Bolton, W. \& Dewar, W. A. (1965). The digestibility of acetic, propionic and butyric acids by the fowl. British Poultry Science 6, 103-105.

Coates, M. E., Fuller, R., Harrison, G. F., Lev, M.\& Suffolk, S. F. (1963). A comparison of the growth of chicks in the Gustafsson germ-free apparatus and in a conventional environment, with and without dietary supplements of penicillin. British Journal of Nutrition 17, 141-150.

Eggum, B. O. \& Chwalibog, A. (1983). A study on energy requirement for maintenance and growth in rats with normal or reduced gut flora. Journal of Animal Physiology and Animal Nutrition 49, 104-114.

Furuse, M. \& Okumura, J. (1989). Effects of acetic acid levels on protein and energy utilization in chicks. Poultry Science 68, 795-798.

Furuse, M. \& Yokota, H. (1984). Protein and energy utilization in germ-free and conventional chicks given diets containing different levels of dietary protein. British Journal of Nutrition 51, 255-264.

Harris, P. M. \& Lobley, G. E. (1991). Amino acid and energy metabolism in the peripheral tissues of ruminants. In Physiological Aspects of Digestion and Metabolism in Ruminants, pp. 201-230 [T. Tsuda, Y. Sasaki and R. Kawashima, editors]. San Diego: Academic Press, Inc.

Harrison, G. F. \& Hewitt, D. (1978). The influence of the conventional microflora on the body temperature of the chick. British Poultry Science 19, 273-275.

Hegde, S. N., Rolls, B. A. \& Coates, M. E. (1982). The effects of the gut microflora and dietary fibre on energy utilization by the chick. British Journal of Nutrition 48, 73-80.

Hill, F. W. \& Anderson, D. L. (1958). Comparisons of metabolizable energy and productive energy determinations with growing chicks. Journal of Nutrition 64, 587-603.

Muramatsu, T., Coates, M. E., Hewitt, D., Salter, D. N. \& Garlick, P. J. (1983). The influence of the gut microflora on protein synthesis in liver and jejunal mucosa in chicks. British Journal of Nutrition 49, 453-462.

Muramatsu, T., Kodama, H., Morishita, T., Furuse, M. \& Okumura, J. (1991). Effect of intestinal microflora on digestible energy and fiber digestibility in chickens fed a high fiber diet. American Journal of Veterinary Research 52, 1178-1181.

Muramatsu, T., Nakajima, S., Furuse, M., Tasaki, I. \& Okumura, J. (1988a). Influence of the gut microflora on basal metabolic rate in chicks. British Poultry Science 29, 307-314.

Muramatsu, T. \& Okumura, J. (1985). Whole-body protein turnover in chicks and early stages of growth. Journal of Nutrition 115, 483-490.

Muramatsu, T., Salter, D. N. \& Coates, M. E. (1985). Protein turnover of breast muscle in germ-free and conventional chicks. British Journal of Nutrition 54, 131-145.

Muramatsu, T., Takasu, O., Furuse, M. \& Okumura, J. (1988b). Effect of diet type on enhanced intestinal protein synthesis by the gut microflora in the chick. Journal of Nutrition 118, 1069-1074. 
Muramatsu, T., Takasu, O., Furuse, M., Tasaki, I. \& Okumura, J. (1987). Influence of the gut microflora on protein synthesis in tissues and in the whole body of chicks. Biochemical Journal 246, 475-479.

Muramatsu, T., Takemura, J. \& Okumura, J. (1993). Acetic acid is not involved in enhanced intestinal protein synthesis by the presence of the gut microflora in chickens. Comparative Biochemistry and Physiology 105A. 543-548.

Okumura, J, Hewitt, D. \& Coates, M. E. (1978). Nitrogen excretion in germ-free and conventional chickens: effects of an alkali load. British Journal of Nutrition 39, 99-104.

Salter, D. N. \& Coates, M. E. (1971). The influence of the gut microflora of the alimentary tract on protein digestion in the chick. British Journal of Nutrition 26, 55-69.

Salter, D. N., Coates, M. E. \& Hewitt, D. (1974). The utilization of protein and excretion of uric acid in germfree and conventional chicks. British Journal of Nutrition 31, 307-318.

Snedecor, G. W. \& Cochran, W. G. (1980). In Statistical Methods, 7th ed., pp. 298-333. Ames: Iowa State University Press.

Statistical Analysis Systems Institute Inc. (1985). In SAS User's Guide: Statistics, version 5. Cary, NC: SAS Institute Ine.

Yen, J. T., Neinaber, J. A., Pond, W. G. \& Varel, V. H. (1985). Effect of carabadox on growth, fasting metabolism, thyroid function and gastrointestinal tract in young pigs. Journal of Nutrition 115, 970-979.

Yokota, H., Furuse, M., Okumura, J. \& Tasaki, I. (1984). A simple method for production and rearing of the germ-free chick. Japanese Journal of Zootechnical Science 55, 600-603.

Yoshida, M., Morimoto, H. \& Oda, R. (1970). Availability of energy in aliphatic carboxylic acids by growing chicks. Agricultural and Biological Chemistry 34, 1301-1307. 